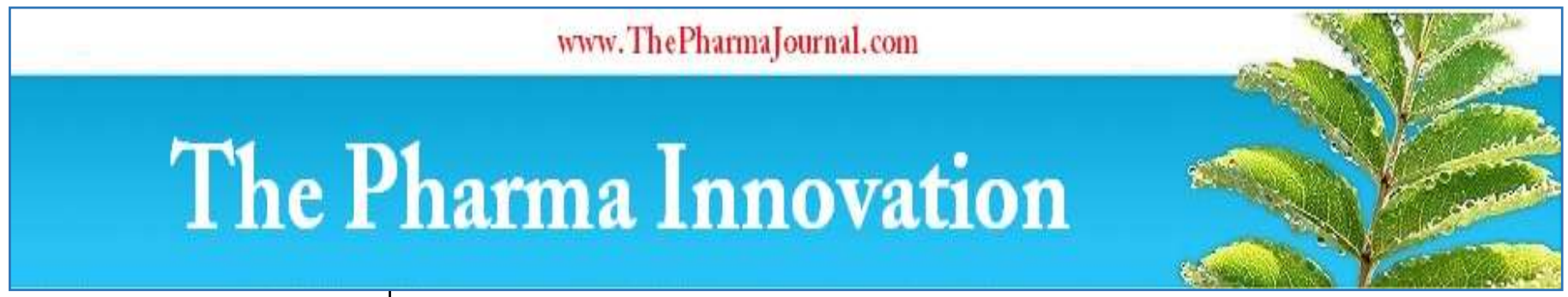

ISSN (E): 2277- 7695

ISSN (P): 2349-8242

NAAS Rating: 5.23

TPI 2021; SP-10(3): 168-171

(C) 2021 TPI

www.thepharmajournal.com

Received: 11-12-2020

Accepted: 28-01-202

\section{Aditi Dutt}

Department of HDFS, College of

Home Science, G.B. Pant

University of Agriculture \&

Technology, Uttarakhand, India

Ritu Singh

Department of HDFS, College of

Home Science, G.B. Pant

University of Agriculture \&

Technology, Uttarakhand, India

\section{Akriti Dut}

Department if GPB, College of Agriculture, N.D. University of Agriculture \& Technology, Uttar

Pradesh, India

Corresponding Author: Aditi Dutt

Department of HDFS, College of

Home Science, G.B. Pant

University of Agriculture \&

Technology, Uttarakhand, India

\section{Young adulthood: fluctuating "attachment bonds" at the on-set of romantic relationship}

\author{
Aditi Dutt, Ritu Singh and Akriti Dutt
}

DOI: https://doi.org/10.22271/tpi.2021.v10.i3Sc.5872

\begin{abstract}
Attachment is a basic need of every creature which varies at different stages of life for various reasons: to survive, gain security and form a lineage. Young adulthood is a period of drastic changes which take place in every domain of life. The emotional development of young adults is totally dependent upon their parents and peer circle. But the arrival of a romantic partner, creates a change in the attachment dynamics of young adults. Holding on to this thought, the present study was undertaken to identify the occurrence of changes in the attachment style of romantically involved young adults. The sample comprised of a total of 400 college students (200 Graduates, and 200 Above Graduates) who were currently in a relationship selected using snowball sampling technique under two populations i.e. GBPUA\&T, Pantnagar, and PAU, Ludhiana Universities. A self-reporting questionnaire was employed. Students were asked to submit the questionnaire anonymously in an envelope addressed to the researcher for the confidentiality of their responses. Findings reveal that graduates were seen to be having a secure attachment with parents whereas; above graduates were highly inclined towards secure peer attachment. Dismissing attachment style with peers was highly prevalent in graduates, on the contrary, above graduates were seen to be highly dismissive towards their parents.
\end{abstract}

Keywords: Attachment, young-adult, secure, dismissing, graduates, above graduates, romantic relationship

\section{Introduction}

Young adulthood is characterized as a time of dramatic changes, which take place in all aspects of life. Transitioning from school and familiar setting to college and dormitory lifestyle, entering in a romantic relationship, forming a close friend circle, and starting a career represents the variability of this stage. Leaving home plays a key role in young adult's parent and peer attachment.

Humans are social creatures who are driven by their need to belong (Leary and Baumeister, 2000) ${ }^{[13]}$, which makes them formulate different kinds of relations and maintain them throughout their life. Among all of them, the relationship with the romantic partner is of utmost importance. The foundation of this relationship is love which is one of the most intense and ubiquitous emotions known to a human being. But it is also known that one's adult-life is the echo of one's childhood so developing attachment, love, and nurturance of parents is essential. According to Bowlby (1969) ${ }^{[1]}$ childhood provides the base for further relationships and molds one's personality for an entire lifetime. He also said that a close friend or long-term romantic partner replaces a parent as the primary attachment figure (Fraley and Davis, 1997; Hazan and Zeifman, 1999; van Ijzendoorn and Sagi-Schwartz, 2008) ${ }^{[6,10,19]}$. Furman and Wehner (1994) [7] offer a behavioral systems approach to understanding the various developmental tasks accomplished by adolescent romance. The four systems invoked in adolescent romantic relationships are affiliative, sexual/reproductive, attachment, and caregiving. Furman and Wehner arrive at this conceptualization of adolescent romantic relationships by merging ideas from attachment theory (e.g. Hazen and Shaver, 1987) ${ }^{[9]}$ and Sullivan's (1953) ${ }^{[17]}$, the theory of social needs in key relationships from infancy through adolescence. Furman and Wehner (1994) [7], suggest that the affiliative and sexual/reproductive systems are active in adolescent romance before the attachment and caregiving systems develop. In fact, these latter two systems may not manifest until early adulthood. The behavioral systems model suggests that systems are engaged in a cumulative fashion, rather than a progression where one system gives way to another. For example, when the attachment system is active in a relationship, the sexual/reproductive and affiliative systems are also likely to be active in that relationship. 
But this does not mean that the attachment bond between parents and young adults is broken; it simply shows the expansion and development of attachment. Hence, various studies reflect that young adults 'attachment needs differ between familial, friend, and romantic relationships (Trinke and Bartholomew, 1997; Pierce and Lydon, 2001; Overall, Fletcher and Friesen, 2003) [18, 15, 14]. For whatever reasons, the longing to form and develop a meaningful relationship is present in every human being. The need of forming a romantic relationship arises when there is a constant fluctuation in the interpersonal relationship (parents, peers, and siblings). This mainly occurs at the time of transition from adolescents to young adults. The intensity and nature of interpersonal relationships suddenly change according to the person. Now, young adults form specific relationships according to their interpersonal needs because these relationships help to meet the emotional need and goals of young people. In various relationships, forming a bond of attachment with multiple people for security and closeness; age act as a predictor of social expansion (Furman, 2009; Carr, 2012; Sukys, Lisinskiene, and Tilindiene, 2015) ${ }^{[8,3,16]}$. The present study focuses on the changes in the parent and peer relationship of romantically involved young adults across age.

\section{Material and Methods \\ Data Collection}

400 Students (200 Graduates, and 200 Above Graduates) who were currently in a relationship selected using snowball sampling technique under two populations i.e. GBPUA\&T Pantnagar, and PAU Ludhiana Universities. A self-reporting questionnaire was employed. Students were asked to submit the questionnaire anonymously in an envelope addressed to the researcher for the confidentiality of their responses. SPSS20 has been used for data analysis.

\section{Research Tool}

Behavior System Questionnaire (BSQ) designed by Furman \& Wehner, (1994) ${ }^{[7]}$; Furman, Simon, Shaffer, \& Bouchey, (2002), is developed to measure relationship type between romantic partners, parents, and friends. Most sections of the various BSQs are identical, except for the relationship being assessed. For each type of relationship, secure, dismissing, and preoccupied styles were assessed. The scale uses a fivepoint likert format which is " 1 "- strongly agree to " 5 "strongly disagree. For each relationship, three Behavioral Style Scores are calculated. These scores are the average of the three corresponding system scores.

\section{Result and Discussion}

Fig. 1 depicts the mean score of romantically involved Graduates and Post-Graduates on Attachment Style (Towards Parents). In Table 1, an independent sample t-test elaborates the significant difference in parent attachment between romantically involved Undergraduate and post-graduate or above students of GBPUAT, Pantnagar, and PAU, Ludhiana. Findings showed that there is a significant difference $(p<.05)$ between Secure ( $t=3.64)$ and Dismissing ( $t=-3.47)$ style of parent attachment. Under-graduate were observed having a significantly higher secure attachment with parents whereas, post-graduate or above were seen to be having a significantly higher dismissing attachment with their parents. This finding is in resonance with the view of Diamond et al. (2010) ${ }^{[5]}$ who proved that the relationship between emerging adults and their parents has remained strong. Collin and Read (1994) ${ }^{[4]}$, also found that an individual's attachment with parents during early adulthood is firmly established. On the contrary, postgraduate or above were seen to be significantly having a higher dismissing style of attachment with parents. The plausible cause of this may be due to the expanding social circle and the need to form their name in society makes young adults more independent. They want to explore society without being in the shadows of their parents which makes them dismissive towards their parents.

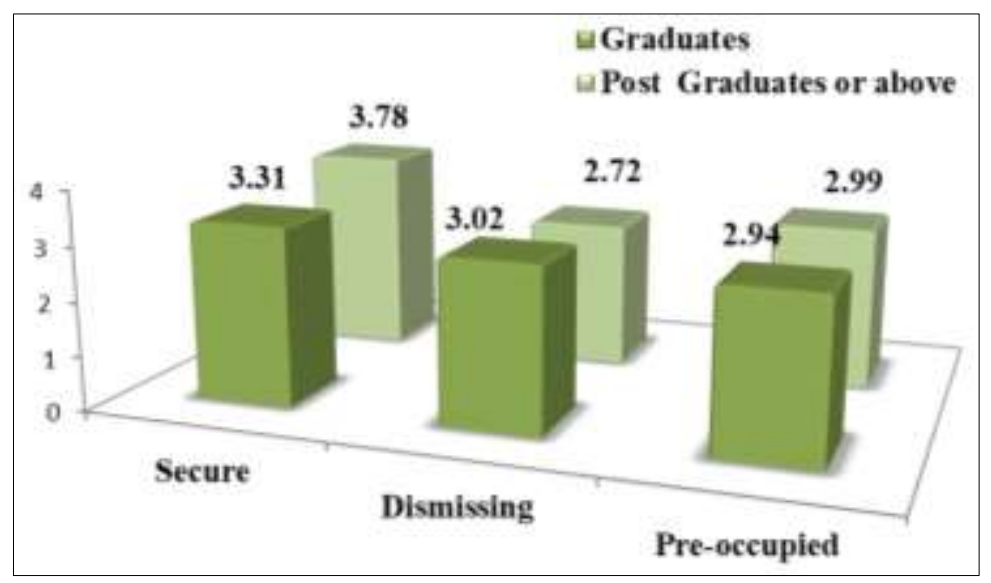

Fig 1: Mean Score of Romantically Involved Graduates and Post-Graduates on Attachment Style (Towards Parents)

Fig. 2 depicts the mean score of romantically involved Graduates and Post-Graduates on Attachment Style (Towards Peers). In table 2, an independent sample t-test represents the significant difference in peer attachment between romantically involved Undergraduate and post-graduate or above students of GBPUAT, Pantnagar, and PAU, Ludhiana. Findings showed that there is a significant difference $(p<0.05)$ between Secure $(\mathrm{t}=-9.379)$ and Dismissing $(\mathrm{t}=-$ 6.028) style of peer attachment. Post-graduate or above students of both universities were observed having a significantly higher secure style of attachment with peers. On the contrary, under-graduates were seen to be having a significantly higher dismissing style of attachment with peers. This happens due to the occurrence of a romantic relationship; which plays a key role in decreasing the quality of friendship from age 19-23. Because at this stage of life, if romantic partners take the role and functions which were previously played by the friend circle of the young adult it causes the rift between the peer relationships (Lansford et al. 2014) ${ }^{[12]}$. Apart from this personality and individual preferences of 
young adults also affect their quality of peer relationships. Boyce, (2013) ${ }^{[2]}$ found that personality gradually changes over time, and these changes in the personality are related to changes in adult life satisfaction and needs; which further proves that the above graduates have a secure attachment with peers. Secondly, communication and social interactions or skills are also important in forming and entering any peer cliques.

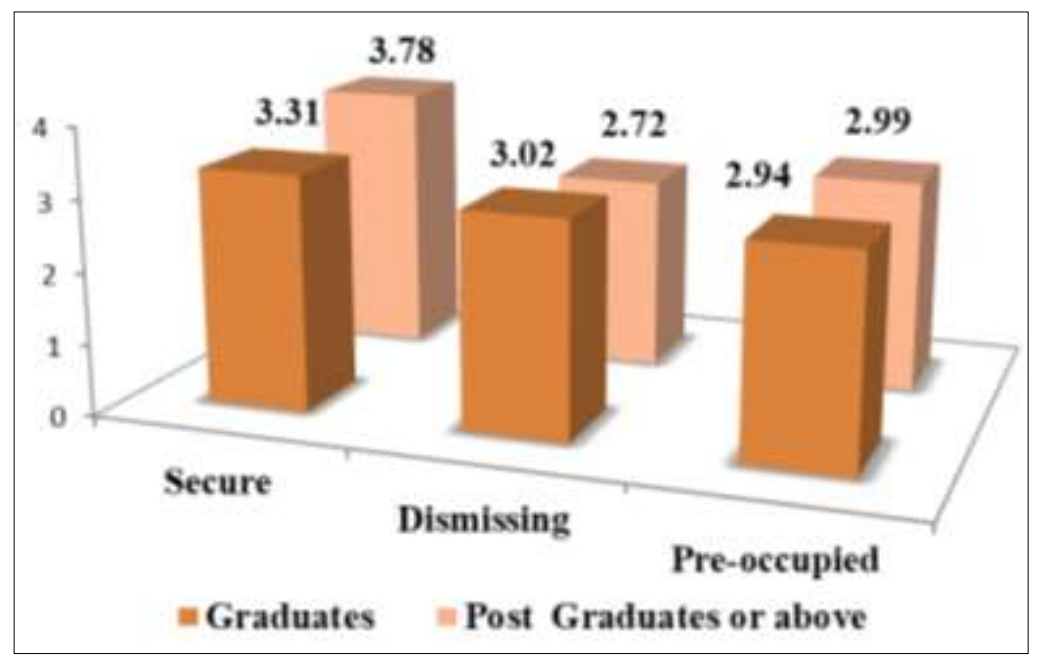

Fig 2: Mean Score of Romantically Involved Graduates and Post-Graduates on Attachment Style (Towards Peers)

A plausible cause for the significant difference in attachment styles could be the age and maturity of the respondents which play a key role in parent and peer attachment. Emerging adulthood is a stressful process in which the transition from school to college takes place. The breaking away process from the primary attachment bonds will occur at a slower pace before they can develop new relationships with others aside from primary caregivers. Therefore, it is fair to say that younger individuals experience a need to be attached to parents until they gain enough confidence to explore new environments by themselves. Respondents achieve independence and autonomy as they grow older. Their pattern of proximity seeking of a secure base provided by their parents will change as they develop the ability of effective self-regulation. Young adulthood is a distinct period of life which opens the door of different goals, responsibilities, priorities, role, and competence that helps respondents in developing attachment behavior both, for example, in terms of how much emotional support is requested and from whom the support is sought; this reflects that the secured attachment style varies across the network of relationships and age (La Gaurdia, Ryan, Couchman and Deci, 2000) [11]. Peer attachment develops over the period of young adulthood; where they explore and get a new experience of peer relationships. They seek close proximity from the secure base, during their prolonged stay in college/university for higher studies which is provided by their peers who seemed more inviting than to try and get connected to their parents who lived apart from them. Apart from this, individual factors, family, and cultural factors also affect the attachment style of young adults.

\section{Conclusion}

Throughout the lifespan, an individual is able to formulate a variety of context-specific attachments with various figures (parent, peer, and romantic partner). This study shed light on the 'attachment style' of romantically involved young adults with their parent and peer; which fluctuates at different lifestage and the emotional requirement. It shows that young adults place significant importance on a particular relation/person at different ages. The findings of this study can be helpful for the parents and peers who have problems with the occurrence of a change in behavior of their offspring/friend at different stages and social settings of life. It helps them understand that attachment can change at every different movement but, this does not employ that it declines during the growth and development of individuals. It is established with parents, peers and romantic partners only add an additional level of complexity by making it relationshipspecific.

Table 1: Independent sample t-test for romantically involved Under-graduate and Post-graduate or above students of GBPUAT, Pantnagar and PAU, Ludhiana on Parent Attachment

\begin{tabular}{|c|c|c|c|c|c|c|c|c|c|c|}
\hline \multicolumn{11}{|c|}{ Independent Samples Test } \\
\hline \multirow{3}{*}{\multicolumn{2}{|c|}{ Types of attachment }} & \multicolumn{2}{|c|}{$\begin{array}{c}\text { Levene's Test for Equality } \\
\text { of Variances }\end{array}$} & \multicolumn{7}{|c|}{ t-test for Equality of Means } \\
\hline & & \multirow[t]{2}{*}{$\mathbf{F}$} & \multirow[t]{2}{*}{ Sig. } & \multirow[t]{2}{*}{$\mathbf{t}$} & \multirow[t]{2}{*}{ df } & \multirow[t]{2}{*}{$\begin{array}{c}\text { Sig. } \\
\text { (2-tailed) }\end{array}$} & \multirow[t]{2}{*}{$\begin{array}{c}\text { Mean } \\
\text { Difference }\end{array}$} & \multirow[t]{2}{*}{$\begin{array}{l}\text { Std. Error } \\
\text { Difference }\end{array}$} & \multicolumn{2}{|c|}{$\begin{array}{l}\text { 95\% Confidence } \\
\text { Interval of the } \\
\text { Difference }\end{array}$} \\
\hline & & & & & & & & & Lower & Upper \\
\hline \multirow{2}{*}{ Secure } & $\begin{array}{c}\text { Equal variances } \\
\text { assumed }\end{array}$ & 11.049 & .001 & 3.647 & 398 & .000 & .19800 & .05429 & .09128 & .30472 \\
\hline & $\begin{array}{c}\text { Equal variances } \\
\text { not assumed }\end{array}$ & & & 3.647 & 376.510 & .000 & .19800 & .05429 & .09126 & .30474 \\
\hline Dismissing & $\begin{array}{c}\text { Equal variances } \\
\text { assumed }\end{array}$ & 2.335 & .127 & -3.476 & 398 & .001 & -.16900 & .04862 & -.26458 & -.07342 \\
\hline
\end{tabular}




\begin{tabular}{|c|c|c|c|c|c|c|c|c|c|c|}
\hline & $\begin{array}{c}\text { Equal variances } \\
\text { not assumed }\end{array}$ & & & -3.476 & 385.118 & .001 & -.16900 & .04862 & -.26459 & -.07341 \\
\hline \multirow{2}{*}{ Preoccupied } & $\begin{array}{c}\text { Equal variances } \\
\text { assumed }\end{array}$ & 3.676 & .056 & 1.246 & 398 & .214 & .05500 & .04415 & -.03179 & .14179 \\
\hline & $\begin{array}{c}\text { Equal variances } \\
\text { not assumed }\end{array}$ & & & 1.246 & 395.143 & .214 & .05500 & .04415 & -.03180 & .14180 \\
\hline
\end{tabular}

Table 2: Independent sample t-test for romantically involved Under-graduate and Post-graduate or above students of GBPUAT, Pantnagar and PAU, Ludhiana on Peer Attachment

\begin{tabular}{|c|c|c|c|c|c|c|c|c|c|c|}
\hline \multicolumn{11}{|c|}{ Independent Samples Test } \\
\hline \multirow{3}{*}{\multicolumn{2}{|c|}{ Types of attachment }} & \multicolumn{2}{|c|}{\begin{tabular}{|c|} 
Levene's Test for \\
Equality of \\
Variances \\
\end{tabular}} & \multicolumn{7}{|c|}{ t-test for Equality of Means } \\
\hline & & \multirow[t]{2}{*}{$\mathbf{F}$} & \multirow[t]{2}{*}{ Sig. } & \multirow[t]{2}{*}{$\mathbf{t}$} & \multirow[t]{2}{*}{ df } & \multirow[t]{2}{*}{ Sig. (2-tailed) } & \multirow[t]{2}{*}{$\begin{array}{c}\text { Mean } \\
\text { Difference }\end{array}$} & \multirow[t]{2}{*}{$\begin{array}{l}\text { Std. Error } \\
\text { Difference }\end{array}$} & \multicolumn{2}{|c|}{$\begin{array}{c}\text { 95\% Confidence } \\
\text { Interval of the } \\
\text { Difference }\end{array}$} \\
\hline & & & & & & & & & Lower & Upper \\
\hline \multirow{2}{*}{ Secure } & Equal variances assumed & .663 & .416 & -9.379 & 398 & .000 & -.47267 & .05040 & -.57175 & -.37359 \\
\hline & Equal variances not assumed & & & -9.379 & 397.745 & .000 & -.47267 & .05040 & -.57175 & -.37359 \\
\hline \multirow{2}{*}{ Dismissing } & Equal variances assumed & .110 & .740 & -6.028 & 398 & .000 & -.29300 & .04861 & -.38856 & -.19744 \\
\hline & Equal variances not assumed & & & -6.028 & 397.755 & .000 & -.29300 & .04861 & -.38856 & -.19744 \\
\hline \multirow{2}{*}{ Preoccupied } & Equal variances assumed & 1.936 & .165 & -1.089 & 398 & .277 & -.05400 & .04959 & -.15148 & .04348 \\
\hline & Equal variances not assumed & & & -1.089 & 391.374 & .277 & -.05400 & .04959 & -.15149 & .04349 \\
\hline
\end{tabular}

\section{References}

1. Bowlby J. Attachment and loss: V. 1: Attachment. New York: Basic Books 1969.

2. Boyce CJ, Wood AM, Powdthavee N. Is personality fixed? Personality changes as much as 'variable' economic factors and more strongly predicts changes to life satisfaction. Social Indicators Research 2013;111:287-305.

3. Carr S. Attachment in Sport, Exercise and Wellness; Routledge: Abingdon-on-Thames, UK 2012. ISBN 9780415578585.

4. Collins NL, Read SJ. Cognitive representations of attachment: The structure and function of working models. In Advances in Personal Relationships. Attachment Processes in Adulthood; Bartholomew, K., Perlman, D., Eds.; Jessica Kingsley: London, UK 1994;5:53-90.

5. Diamond GM, Gallop R, Shelef K, Levy S. Attachmentbased family therapy for adolescents with suicidal ideation: a randomized controlled trial. J Am Acad Child Adolesc Psychiatry 2010;49(2):122-31. Doi: 10.1097/00004583-201002000-00006. PMID: 20215934.

6. Fraley RC, Davis KE. Attachment formation and transfer in young adults'close friendships and romantic relationships. Pers. Relatsh 1997;4:131-144. [CrossRef]

7. Furman W, Wehner EA. Romantic Views: Toward a Theory of Adolescent Romantic Relationships. In R. Montemayor, G. R. Adams, and T. P. Gullotta (Eds.), Personal Relationships during Adolescence 1994, 168195.

8. Furman W, Buhrmester D. The Network of Relationships Inventory: Behavioral Systems Version. Int. J Behav. Dev. 2009;33:470-478. [CrossRef] [PubMed]

9. Hazan C, Shaver P. Romantic Love Conceptualized as an Attachment Process. Journal of Personality and Social Psychology 1987;52(2):511-524.

10. Hazan C, Zeifman D. Pair bonds as attachments: Evaluating the evidence. In Handbook of Attachment: Theory, Research, and Clinical Applications; Cassidy, J., Shaver, P.R., Eds.; Guilford Press: New York, NY, USA 1999, 336-354.
11. La Guardia JG, Ryan RM, Couchman CE, Deci EL. Within-person variation in security of attachment: A selfdetermination theory perspective on attachment, need fulfillment, and well-being. J Personal. Soc. Psychol 2000;79:367-384. [CrossRef]

12. Lansford JE, Tianyi Yu, Pettit GS, Bates JE, Dodge KA. Pathways of peer relationships from childhood to young adulthood. Journal of Applied Developmental Psychology 2014;35(2):111-117. https://doi.org/10.1016/j.appdev.2013.12.002.

13. Leary MR, Baumeister RF. The nature and function of self-esteem: Sociometer theory. Advances in Experimental Social Psychology 2000;32:1-62.

14. Overall NC, Fletcher GJO, Friesen MD. Mapping the Intimate Relationship Mind: Comparisons between Three Models of Attachment Representations. Personal. Soc. Psychol. Bull 2003;29:1479-1493. [CrossRef] [PubMed]

15. Pierce T, Lydon JE. Global and specific relational models in the experience of social interactions. J Personal. Soc. Psychol 2001;80:613-631. [CrossRef]

16. Sukys S, Lisinskiene A, Tilindiene I. Adolescents' Participation in Sport Activities and Attachment to Parents and Peers. Soc. Behav. Personal. Int. J 2015;43:1507-1517. [CrossRef]

17. Sullivan HS. The interpersonal theory of psychiatry. New York: Norton 1953.

18. Trinke SJ, Bartholomew K. Hierarchies of Attachment Relationships in Young Adulthood. J. Soc. Pers. Relat 1997;14-603-625. [CrossRef]

19. Van Ijzendoorn MH, Sagi-Schwartz. A. Cross-cultural patterns of attachment: Universal and contextual dimensions. In Handbook of Attachment: Theory, Research, and Clinical Applications; Cassidy, J., Shaver, P.R., Eds.; Guilford Press: New York, NY, USA 2008, 880-905. 